NASA/TM-2002-211705
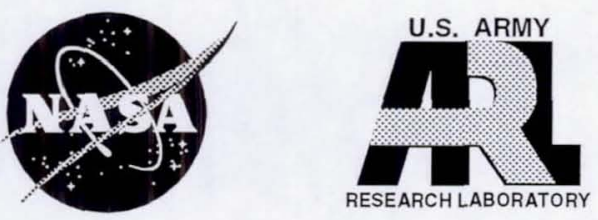

\title{
The Role of Radial Clearance on the Performance of Foil Air Bearings
}

Kevin Radil

U.S. Army Research Laboratory, Glenn Research Center, Cleveland, Ohio

Samuel Howard

Glenn Research Center, Cleveland, Ohio

Brian Dykas

Ohio Aerospace Institute, Brook Park, Ohio 
The NASA STI Program Office ... in Profile

Since its founding, NASA has been dedicated to the advancement of aeronautics and space science. The NASA Scientific and Technical Information (STI) Program Office plays a key part in helping NASA maintain this important role.

The NASA STI Program Office is operated by Langley Research Center, the Lead Center for NASA's scientific and technical information. The NASA STI Program Office provides access to the NASA STI Database, the largest collection of aeronautical and space science STI in the world. The Program Office is also NASA's institutional mechanism for disseminating the results of its research and development activities. These results are published by NASA in the NASA STI Report Series, which includes the following report types:

- TECHNICAL PUBLICATION. Reports of completed research or a major significant phase of research that present the results of NASA programs and include extensive data or theoretical analysis. Includes compilations of significant scientific and technical data and information deemed to be of continuing reference value. NASA's counterpart of peerreviewed formal professional papers but has less stringent limitations on manuscript length and extent of graphic presentations.

- TECHNICAL MEMORANDUM. Scientific and technical findings that are preliminary or of specialized interest, e.g., quick release reports, working papers, and bibliographies that contain minimal annotation. Does not contain extensive analysis.

- CONTRACTOR REPORT. Scientific and technical findings by NASA-sponsored contractors and grantees.
- CONFERENCE PUBLICATION. Collected papers from scientific and technical conferences, symposia, seminars, or other meetings sponsored or cosponsored by NASA.

- SPECIAL PUBLICATION. Scientific, technical, or historical information from NASA programs, projects, and missions, often concerned with subjects having substantial public interest.

- TECHNICAL TRANSLATION. Englishlanguage translations of foreign scientific and technical material pertinent to NASA's mission.

Specialized services that complement the STI Program Office's diverse offerings include creating custom thesauri, building customized data bases, organizing and publishing research results ... even providing videos.

For more information about the NASA STI Program Office, see the following:

- Access the NASA STI Program Home Page at http://www.sti.nasa.gov

- E-mail your question via the Internet to help@sti.nasa.gov

- Fax your question to the NASA Access Help Desk at 301-621-0134

- Telephone the NASA Access Help Desk at 301-621-0390

- Write to:

NASA Access Help Desk

NASA Center for AeroSpace Information 7121 Standard Drive

Hanover, MD 21076 
NASA/TM-2002-211705
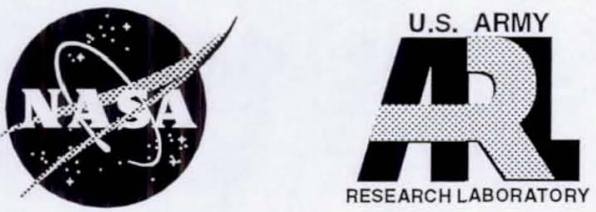

\section{The Role of Radial Clearance on the Performance of Foil Air Bearings}

Kevin Radil

U.S. Army Research Laboratory, Glenn Research Center, Cleveland, Ohio

Samuel Howard

Glenn Research Center, Cleveland, Ohio

Brian Dykas

Ohio Aerospace Institute, Brook Park, Ohio

Prepared for the

International Joint Tribology Conference

cosponsored by the American Society of Mechanical Engineers

and the Society of Tribologists and Lubrication Engineers

Cancun, Mexico, October 27-30, 2002

National Aeronautics and

Space Administration

Glenn Research Center 
This report contains preliminary findings, subject to revision as analysis proceeds.

The Aerospace Propulsion and Power Program at NASA Glenn Research Center sponsored this work.

Available from

NASA Center for Aerospace Information

7121 Standard Drive

Hanover, MD 21076
National Technical Information Service 5285 Port Royal Road Springfield, VA 22100 


\title{
The Role of Radial Clearance on the Performance of Foil Air Bearings
}

\author{
Kevin Radil \\ U.S. Army Research Laboratory \\ National Aeronautics and Space Administration \\ Glenn Research Center \\ Cleveland, Ohio 44135 \\ Samuel Howard \\ National Aeronautics and Space Administration \\ Glenn Research Center \\ Cleveland, Ohio 44135 \\ Brian Dykas \\ Ohio Aerospace Institute \\ Brook Park, Ohio 44142
}

\begin{abstract}
Load capacity tests were conducted to determine how radial clearance variations affect the load capacity coefficient of foil air bearings. Two Generation III foil air bearings with the same design but possessing different initial radial clearances were tested at room temperature against an as-ground PS304 coated journal operating at $30000 \mathrm{rpm}$. Increases in radial clearance were accomplished by reducing the journal's outside diameter via an in-place grinding system. From each load capacity test the bearing load capacity coefficient was calculated from the rule-of-thumb (ROT) model developed for foil air bearings.

The test results indicate that, in terms of the load capacity coefficient, radial clearance has a direct impact on the performance of the foil air bearing. Each test bearing exhibited an optimum radial clearance that resulted in a maximum load capacity coefficient. Relative to this optimum value are two separate operating regimes that are governed by different modes of failure. Bearings operating with radial clearances less than the optimum exhibit load capacity coefficients that are a strong function of radial clearance and are prone to a thermal runaway failure mechanism and bearing seizure. Conversely, a bearing operating with a radial clearance twice the optimum suffered only a $20 \%$ decline in its maximum load capacity coefficient and did not experience any thermal management problems. However, it is unknown to what degree these changes in radial clearance had on other performance parameters, such as the stiffness and damping properties of the bearings.
\end{abstract}

\section{Introduction}

Compliant foil air bearings rely on an in-series arrangement of pressure forces from the selfgenerated hydrodynamic air film and structural elastic forces to provide support for a rotordynamic system. Since foil air bearings utilize ambient air as the lubricant they do not adhere to the same speed and temperature limitations imposed on conventional oil lubricated roller and journal bearings. In fact, they have been demonstrated operating at extreme temperatures (to $650^{\circ} \mathrm{C}$ ) and speeds well above 3 million DN (refs. 1 and 2). Foil air bearings were first commercialized in the 1970's in air cycle machines for aircraft cabin pressurization and more advanced designs are now being researched for applications operating at high speed such as turbochargers, auxiliary power units (APU's), cryogenic turbocompressors and small gas turbine engines for power generation (refs. 3 to 5). 
In 1953 a paper by Blok and VanRossum first introduced the technical community to foil bearings (ref. 6). Since then a myriad of patents and research papers have been published on this subject. However, most of the papers are focused on either theoretical modeling of the bearing, results from their incorporation into specific applications and operating conditions or start-stop wear resistant coatings. Lacking is the in-depth research needed to fully understand the basic operating fundamentals uniquely inherent to foil air bearings as well as the data required to validate computer models. To put this technical deficiency into perspective, Dudley Fuller states that there are thousands of papers in the technical literature dealing with the design and performance of conventional fluid film journal bearings (ref. 7). In contrast, there is little experimental data available to help guide the design and use of foil air bearings and, without this information, future enhancements in foil bearing technology will progress slowly. It has only been during the last ten years that a small number of researchers have begun to address this problem (refs. 8 to 12).

To help foster the maturation of foil air bearing technology, research was conducted to investigate how variations in a design parameter, known as radial clearance or "sway space" by some authors, affected the performance of foil air bearings. Radial clearance can be a confusing concept, especially to people familiar with rigid fluid-film journal bearings, since a foil bearing at rest does not have a perceivable gap between the bearing's top foil and the shaft surface. The lack of a gap is an inherent trait designed into the bearing by specifying the open diameter of the top foil smaller than the diameter of the shaft. Therefore, in a foil bearing, the term radial clearance applies to the small amount of shaft radial motion that exists in the bearing while the bearing is sitting idle. In the authors' opinion this shaft motion is made possible from "play" that exists in the elastic support structure, such as between the top and bump foils and the bump foils and bearing shell. In addition, there may also be room for the shaft to move in small spaces created by the top foil not fully conforming to the shaft's round surface.

Radial clearance in a shaft/foil bearing system is measured by performing a load deflection test. A schematic of the test setup is shown in figure 1a and is taken from the report by Ruscitto (ref. 13). The setup consists of the bearing, a dummy shaft with an identical diameter as in the system and a dial indicator to monitor bearing motion. The test begins with the bearing being seated on the shaft by a downward load. An upward load counteracting the downward load is then incrementally increased while concurrently recording the displacement of the shaft. When the upward load overcomes the downward load the bearing lifts off of the shaft and travels up unimpeded until the bearing again becomes seated on the shaft. The test is continued but performed in the opposite direction until the bearing travels back to its original position. An example of the complete cycle of bearing motion is illustrated by the displacement versus load curve in figure $1 \mathrm{~b}$. Once the curve is obtained radial clearance is determined by following a somewhat subjective procedure of marking the boundaries of low bearing stiffness on the curve, in this case with x's, and then measuring the distance between these two points.

As mentioned in the preceding paragraph the top foil's open diameter is designed to be smaller than the diameter of the shaft. When a shaft is inserted into the bearing the top foil is expanded against the bump foils where small deformations are induced in the bump foils. The bump foils react to these deformations with elastic compression forces that push back on the top foil. Not only do these compression forces hold the top foil in contact with the shaft but they also manifest into a form of bearing preload. One of the factors that helps to define the magnitude of this preload is the amount of available radial clearance. For example, previous tests in the authors' lab on bearings operating with oversized shafts have exhibited a number of problems, such as difficulty assembling the bearing/shaft system, excessive start-up torque and diminished maximum load capacity. These problems were attributed to the bearing being highly preloaded due to the oversized shaft expending the available radial clearance. On the other hand it has been previously reported that if the clearance is excessive the resulting low bearing preload will reduce load capacity and will also adversely affect the bearing's stiffness and damping properties. Additionally, a lightly preloaded bearing might even cause the rotating system to become unstable at the operating point of the application (ref. 14). In between these extremes lies a range of radial clearances that will enable the bearing to provide adequate performance. Determining this range, along with the sensitivity of bearing load capacity to radial clearance, is the focus of this paper. 
The purpose of this work was to investigate how changes in radial clearance affect the load capacity coefficient of foil air bearings through a parametric study on two similar Generation III foil air bearings, as defined in reference 15 , with different initial radial clearances (i.e., preloads). Modification to the radial clearance was accomplished by incrementally reducing the outside diameter of the mating journal using an in-place grinding system. The journal was coated with NASA PS304, a high-temperature solid lubricant coating (ref. 16). Tests were conducted at 30,000 rpm and at room temperature. Resulting bearing load capacity coefficients were based on the maximum steady-state load the bearings were capable of supporting.

\section{Experimental Apparatus/Procedure}

\section{Foil Bearings}

A sketch illustrating the design of the two Generation III foil bearings used in the tests is shown in figure 2. The bearings, labeled as AAS and ADA, are nominally $35 \mathrm{~mm}$ in diameter, $25 \mathrm{~mm}$ long (or wide) and constructed from several layers of nickel-based superalloy foils. The top foil supports the hydrodynamic gas film while the underlying foils, known as bump foils, provide the compliant support structure for the top foil. Along with the air film the bump foils define the bearing's stiffness and also provide Coulomb damping from the frictional microsliding between the top foil and other adjacent surfaces. For a more detailed description of the bearing's construction the reader is referred to the patent (ref .17).

From the load deflection curves provided by the bearing manufacturer it was estimated that bearing ADA's radial clearance was approximately $75 \%$ greater than the clearance in bearing AAS. These curves were generated using a $34.91 \mathrm{~mm}$ diameter dummy shaft in a load range of $\pm 8.9 \mathrm{~N}$.

\section{Test Journals}

The test journal shown in figure 3 is nominally $35 \mathrm{~mm}$ in diameter, $84 \mathrm{~mm}$ long and made from a nickel-based superalloy. A $0.25 \mathrm{~mm}$ deep undercut is machined on the journal to accommodate the deposition of the PS304 solid lubricant coating. The journal has twelve equally spaced threaded holes to accommodate high-speed, in-place dynamic balancing. Changes to the bearing's radial clearance were accomplished by altering the journal's diameter with an in-place grinding system that used a 400 grit diamond impregnated grinding wheel rotating at $5000 \mathrm{rpm}$. Setup of the grinding hardware is shown in figure 4 . The journal was spun in the same direction as the grinding wheel at $700 \mathrm{rpm}$ by a small DC motor coupled to the shaft at the air turbine end of the test rig. The final surface finish of the PS304 coating was approximately $\mathrm{Ra}=0.8 \mathrm{um}$. The grinding system was left in place to facilitate future grinding intervals.

\section{Test Apparatus/Procedure}

The high-speed test rig used to conduct the tests is shown in figure 5 and is described fully in reference 18. The rig consists of a drive shaft that is supported by two hybrid ceramic ball bearings that are lubricated by oil and cooled by temperature-controlled water. An impulse turbine attached to the drive shaft is capable of generating journal rotational speeds up to $70000 \mathrm{rpm}$. Referring to figure 6, radial loading of the bearing is accomplished via a vertical cable system with one end attached to the bearing in a stirrup configuration and the other to a pneumatic load cylinder mounted below the test rig. The rod extending from the bearing loader acts as a moment arm to relay the bearing torque to a load cell.

Preparation for testing began by securing the test journal coated with the PS304 solid lubricant to the high-speed rig. The grinding system was then set in place and its alignment adjusted until the OD of the journal could be ground with a taper of 2.54 um or less over its axial length. The journal was then further ground until a size was reached that produced a slight interference fit with both bearings. A one time set of balance iterations was then performed on the rig in order to reach the test operating speed of $30000 \mathrm{rpm}$. 
The procedure for performing a load capacity test on the two test bearings is as follows. After placing a bearing on the journal the rig was quickly accelerated to the test speed of $30000 \mathrm{rpm}$. This speed was held for a few minutes to thermally stabilize the test rig. Next, the speed was increased by a few thousand rpm and an initial radial load of $22 \mathrm{~N}$ was applied to the bearing. The speed was then decreased back to $30000 \mathrm{rpm}$ and held for 5 minutes while monitoring bearing speed and torque for signs of bearing failure. If failure did not occur the speed was again increased by a few thousand rpm, an additional $22 \mathrm{~N}$ was applied, and the speed reduced back to $30000 \mathrm{rpm}$. This methodology of loading the bearing in $22 \mathrm{~N}$ increments with 5-minute hold periods was continued until the torque and speed output indicated that the hydrodynamic fluid-film was beginning to rupture. When failure was deemed imminent the applied load was removed and the shaft held at $30000 \mathrm{rpm}$ for a few minutes followed by shut down of the rig. The highest successfully supported load was then taken as the input into the ROT model to calculate the load capacity coefficient for the bearing. The ROT model, as defined in reference 15 , is written as

$$
\mathscr{D}=\mathrm{W} / \mathrm{LD}^{2} \Omega
$$

where:

Dis the bearing load coefficient, $\mathrm{N} /\left(\mathrm{mm}^{3} \cdot \mathrm{krpm}\right)$

$\mathrm{W}$ is the maximum steady-state load that can be supported, $\mathrm{N}$

$\mathrm{L}$ is the bearing axial length, $\mathrm{mm}$

$\mathrm{D}$ is the shaft diameter, $\mathrm{mm}$

$\Omega$ is the shaft speed in thousand rpm (krpm)

Upon completion of the first test the journal was quickly cooled to room temperature with a water mist and dried before commencing with the load capacity tests on the second bearing. After testing the second bearing the journal was allowed to cool to room temperature before removing 10 to 15 um from the journal's OD with the in-place grinding system. The load capacity tests were then repeated on the two bearings with the new journal size and the procedure continued until grinding removed the PS304 coating on the journal.

\section{Discussion of Results}

For rigid fluid-film journal bearings load capacity is defined as the load that causes breakdown of the fluid film and sliding contact between surfaces of the journal and shaft (ref. 18). While performing tests being presented it was discovered that light to moderately preloaded compliant foil bearings operating against a PS304 coated journal did not strictly adhere to this definition of load capacity. As shown in figure $7 \mathrm{a}$ when a light radial load was applied, the bearings would exhibit steady behavior in both speed and torque. Ultimately a load would be reached that caused a dramatic increase in torque and a corresponding decrease in journal speed, clear symptoms of rubbing contact and, by the above definition for a fluid-film journal bearing, the load capacity of the bearing. An example of this behavior is depicted by the humps in the torque trace and the erratic behavior of the speed in figure $7 \mathrm{~b}$. However, as demonstrated by the torque trace, the bearing would soon recover load support capability and operation would again be stable. Inspection of the bearing and journal revealed smooth wear marks on the bearing top foil and glossy black wear bands on the PS304 coating surface very similar to surfaces that have endured high temperature start-stop cycles. From this information it is believed that the surfaces were experiencing a fine polishing wear mechanism caused by the high-speed asperity contact between the PS304 coated shaft surface and bearing top foil. This polishing is responsible for renewed support of the applied load since it improves the surface finish of the PS304 coating and top foil by way of enabling a fully developed air film to be restored in the bearing. After making its first appearance this polishing mode continued with each subsequent increase in load until it transitioned into a more severe galling wear mechanism that would cause bearing failure (ref. 19). 
The load capacity coefficients for the two test bearings are graphed in Figure 8 as a function of changes to their initial radial clearance, $\Delta \mathrm{C}$. The graphs are arranged such that the origin of the $\mathrm{x}$-axis corresponds to the initial radial clearance measured by the load deflection test with the $34.91 \mathrm{~mm}$ diameter dummy shaft. Therefore, values to the right of the origin indicate an increase in the initial clearance and those on the left indicate a reduction in the initial clearance. As can be seen from the graph the load capacity coefficients for both bearings follow the same general trend with respect to changes in the radial clearance with AAS's performance lagging behind ADA's because of AAS's tighter initial radial clearance. The graph also shows that there is an optimum radial clearance, $\mathrm{C}_{\mathrm{opt}}$, for each bearing that produces a maximum load capacity coefficient. With respect to these optimum clearances lie two distinct performance regimes differentiated by the modes of failure. If the change in radial clearance is normalized with respect to the optimum clearances and re-graphed, as shown in figure 9 , the regimes can be better highlighted. Designated as regime I, foil bearings with clearances below the optimum were susceptible to a sudden onset of failure characterized by a rapid rise in torque and a corresponding rapid decline in shaft speed. Immediate removal of the applied load did not prevent the bearing and shaft from seizing but did allow the failure to progress without any permanent damage. Symptoms of this failure are indicative of thermal runaway caused by the high bearing preload that resulted from an insufficient amount of radial clearance in the bearing. The high preload consumes a large amount of the hydrodynamic air pressure on expansion of the top foil instead of supporting static loads. As additional load was applied to the bearing during testing the air film became thinner and frictional heating increased. Without sufficient radial clearance thermal expansion of the support structure continued to amplify the bearing preload and frictional heating until the hydrodynamic air film was overwhelmed and the bearing seized. The plausible explanation for this phenomenon is given by DellaCorte (ref. 1) who suggests that foil bearing preload mimics an interference fit with the shaft. Since the bearing and shaft are made from the same material they have the same coefficient of thermal expansion and, as the temperature increases, so does the interference (preload) resulting in thermal runaway. A foil air bearing operating under these conditions would require passing cooling air axially through the bearing in order to remove the excess heat.

Located in regime II foil bearings operating with radial clearances greater than their optimum exhibited a failure mode quite different than if the bearings were highly preloaded as described above. When the maximum load capacity coefficient of the bearing was approached the bearing torque and shaft speed would begin to act erratically thereby giving ample warning of impending failure. Bearing seizure due to thermal runaway was not a concern because there was enough radial clearance to accommodate the tightening of the interference fit due to thermal expansion of the bearing and journal. The graph also indicates that at a certain point the load capacity coefficients for both bearings leveled off even with increasing changes in the radial clearance. In fact, bearing ADA still retained about $80 \%$ of its maximum load capacity coefficient when operating with a radial clearance twice as much as the optimum. The insensitivity of the load capacity coefficient to radial clearance changes may be an indication that the bearing's minimum preload was reached since additional grinding had no effect, at least in the range tested.

These results point to the importance of careful bearing design for the successful operation of high-temperature, high-speed turbomachinery. Special attention should be given to the environmental and operational changes expected in a bearing/shaft system since temperature, centrifugal, and hydrodynamic effects can all impact radial clearance. Otherwise, the bearing/shaft system may behave well under one operating condition but fail under another.

In terms of load support, the results suggest that it might be possible to expand the specified tolerances on some shafting systems for foil bearings since a slightly undersized shaft will not be relinquishing a great deal of performance. If this is the case, the chances for thermal runaway will be reduced along with lower manufacturing costs. 
It is important for the reader to also understand that load capacity is not the only operating parameter that is influenced by radial clearance. At least two others, stiffness and damping, are characteristics that must be considered since they have a direct correlation to the rotordynamic stability of the supported shaft system. For example, greater clearances may alleviate thermal runaway concerns but the resulting increase in fluid film thickness will reduce the bearing's stiffness. Also, structural damping will be adversely affected since shaft motion is restricted to the soft air film instead of being transmitted to the support structure where Coulomb damping occurs. Therefore, in order to understand these issues, additional research is needed that will focus on the relationship between radial clearance and the stiffness and damping properties of foil bearings.

\section{Concluding Remarks}

The results presented herein indicate that radial clearance has a dramatic effect on the load capacity coefficient of foil bearings. The two Generation III bearings tested exhibited their own optimal radial clearance that produced maximum load capacity coefficients. Relative to the optimum were two distinct regimes that were identified. Bearings operating with radial clearances below the optimum were classified as being highly preloaded and suffered from a thermal runaway and low load capacity coefficients. Conversely, bearings with radial clearances larger than the optimum were lightly preloaded and exhibited a decrease in the maximum load capacity coefficient of $20 \%$ or less without any thermal issues. The work presented in this paper is expected to aid in the design and integration of foil air bearing technology into high speed, high temperature turbomachinery applications.

\section{References}

1. DellaCorte, C., Valco, M.J., Radil, K.C. and Heshmat, H.: "Performance and Durability of High Temperature Foil Air Bearings for Oil-Free Turbomachinery," NASA/TM - 2000-209187, 1999.

2. Heshmat, H.: "Advancements in the Performance of Aerodynamic Foil Journal Bearings: High Speed and Load Capability," ASME Jour. of Trib., Vol. 116, pp. 287-295, April 1994.

3. Barnett, M.A., and Silver, A.: "Application of Air Bearings to High-Speed Turbomachinery," SAE Paper 700720, September 1970.

4. Heshmat, H., Walton, J.F., DellaCorte, C., and Valco, M.: "Oil-Free Turbocharger Demonstration Paves Way to Gas Turbine Engine Applications," Presented at the ASME International Gas Turbine and Aeroengine Congress and Exhibition, Munich, Germany, May 8-11, 2000, Paper No. 2000-GT-620.

5. Agrawal, G.L.: "Foil Gas Bearings for Turbomachinery." Soc. of Automotive Engineers, Paper Number 901236, 1990.

6. Blok, H., and VanRossum, J.J.: "The Foil Bearing-A New Departure in Hydrodynamic Lubrication," ASLE Lubrication Engineering, pp. 316-330, December 1953.

7. Fuller, D.: "Theory and Practice of Lubrication for Engineers", 2nd Edition, John Wiley and Sons, Inc., pp. 262-263, 1984.

8. Heshmat, H. and Ku, C.-P.R.: "Effects of Frequency on Structural Stiffness and Damping in a SelfActing Compliant Foil Journal Bearing," ASME International Gas Turbine and Aerospace Congress and Exposition, The Hague, Netherlands, June 13-16, 1994, ASME Paper 94-GT-100.

9. Ku, C.-P.R., and Heshmat, H.: "Effects of Static Load on Dynamic Structural Properties in a Flexible Supported Foil Journal Bearing," ASME Trans., J. of Vibration and Acoustics., Vol. 116, No. 3, pp. 257-262, 1994.

10. Ku, C.-P.R. and Heshmat, H.: "Compliant Foil Bearing Structural Stiffness Analysis-Part II: Experimental Investigation," ASME Journal of Tribology, Vol. 115, No.3, pp. 364-369, 1993. 
11. Howard, S.A., DellaCorte, C., Valco, M.J., Heshmat, H. and Prahl, J.M.: "Dynamic Stiffness and Damping Characteristics of a High Temperature Air Foil Journal Bearing," STLE Tribology Transactions, Vol. 44, No. 4, pp. 657-663, 2001.

12. Carpino, M. and Peng, J-P.: "Theoretical Performance of Foil Journal Bearings," Presented at the AIAA/SAE/ASME/ASEE 27th Joint Propulsion Conference, Sacramento, CA, June 24-26, 1991, AIAA Paper 91-2105.

13. Ruscitto, D., McCormick, J., and Gray, S.: "Hydrodynamic Air Lubricated Compliant Surface Bearing for an Automotive Gas Turbine Engine - I - Journal Bearing Performance," NASA CR135368, April 1978.

14. Suriano, F.J.: "Gas Foil Bearing Development Program", Tech Report AFWAL-TR-81-2085, Garrett Turbine Engine Company, Phoenix, AZ, September 1981.

15. DellaCorte, C. and Valco, M.J.: "Load Capacity Estimation of Foil Air Journal Bearings for Oil-Free Turbomachinery Applications," Tribology Transactions, Vol. 43, 2000, pp. 795-801.

16. DellaCorte, C.: "The Evaluation of a Modified Chrome Oxide Based High Temperature Solid Lubricant Coating for Foil Gas Bearings," NASA TM-208660, 1998.

17. Heshmat, H.: "High Load Capacity Compliant Foil Hydrodynamic Journal Bearing," U.S. Patent \#5,988,885, Nov. 1999.

18. DellaCorte, C.: “A New Foil Air Bearing Test Rig for Use to $700^{\circ} \mathrm{C}$ and 70,000 rpm," NASA TM$107405,1997$.

19. Radil, K.C.: "The Effect of Journal Roughness and Foil Coatings on the Performance of Heavily Loaded Foil Air Bearings," NASA TM-210941, 2001. 


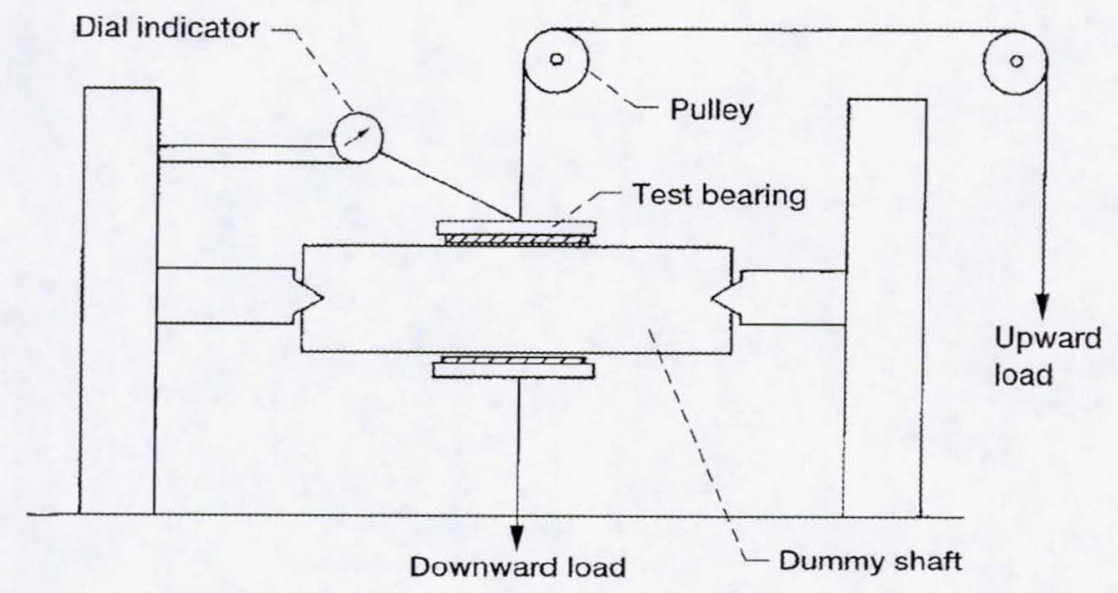

Figure 1a.-Schematic of the setup used to conduct a load deflection test on a foil air bearing.

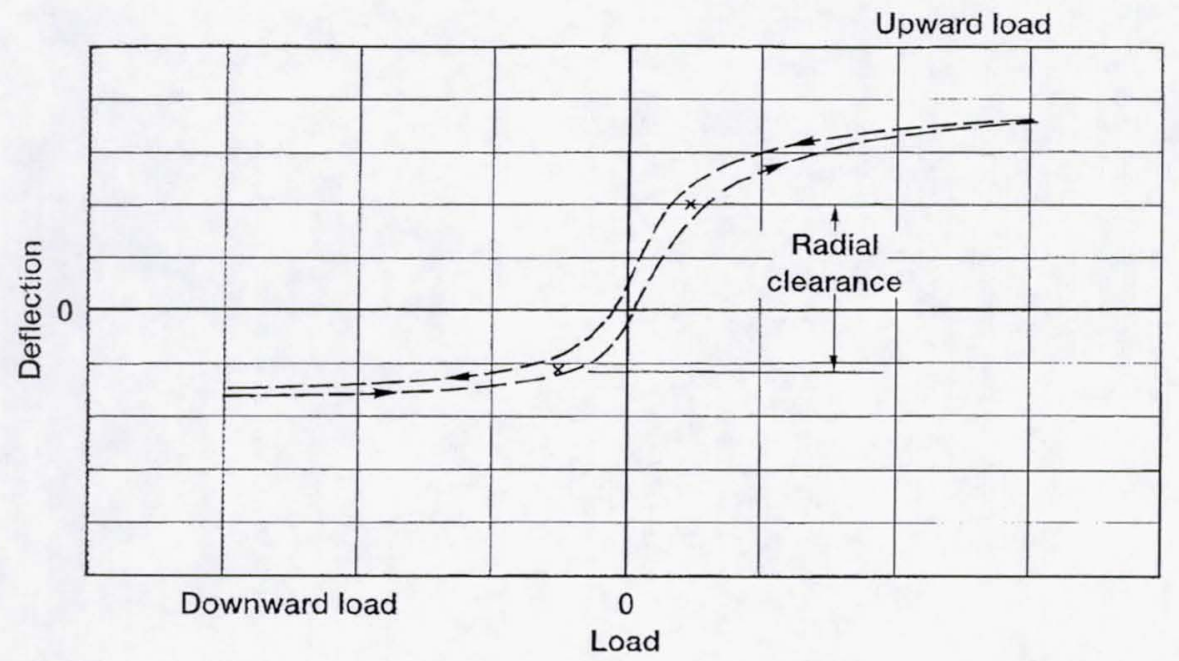

Figure 1b.- Resulting plot of bearing displacement versus load from performing a load deflection test on a foil air bearing. Radial clearance is determined from measuring the distance between the x's. 


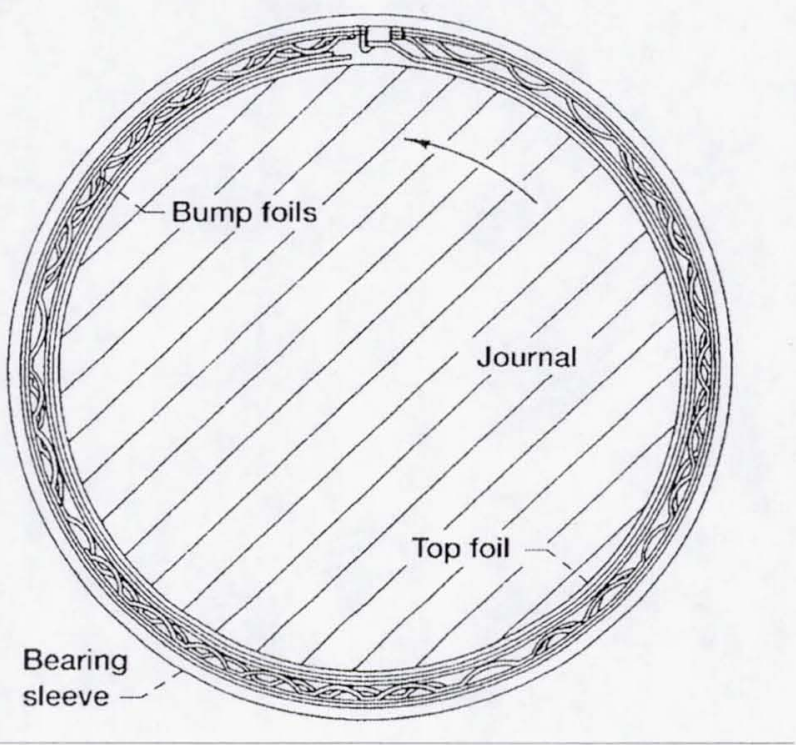

Figure 2.-Drawing of a Generation III foil air bearing.

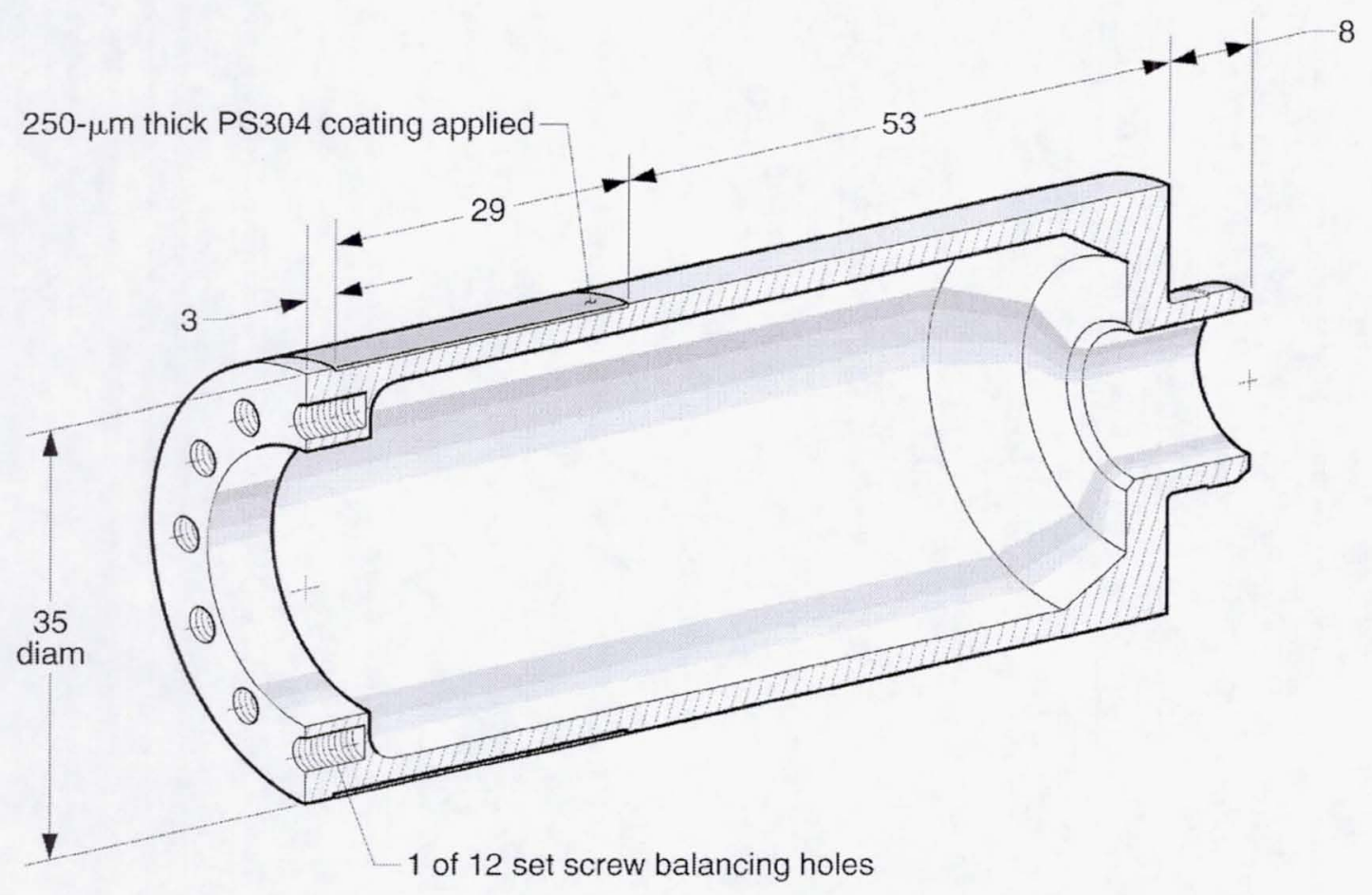

Figure 3.- Schematic of the test journal for the high-temperature, high-speed foil air bearing test rig. Measurements in millimeters. 


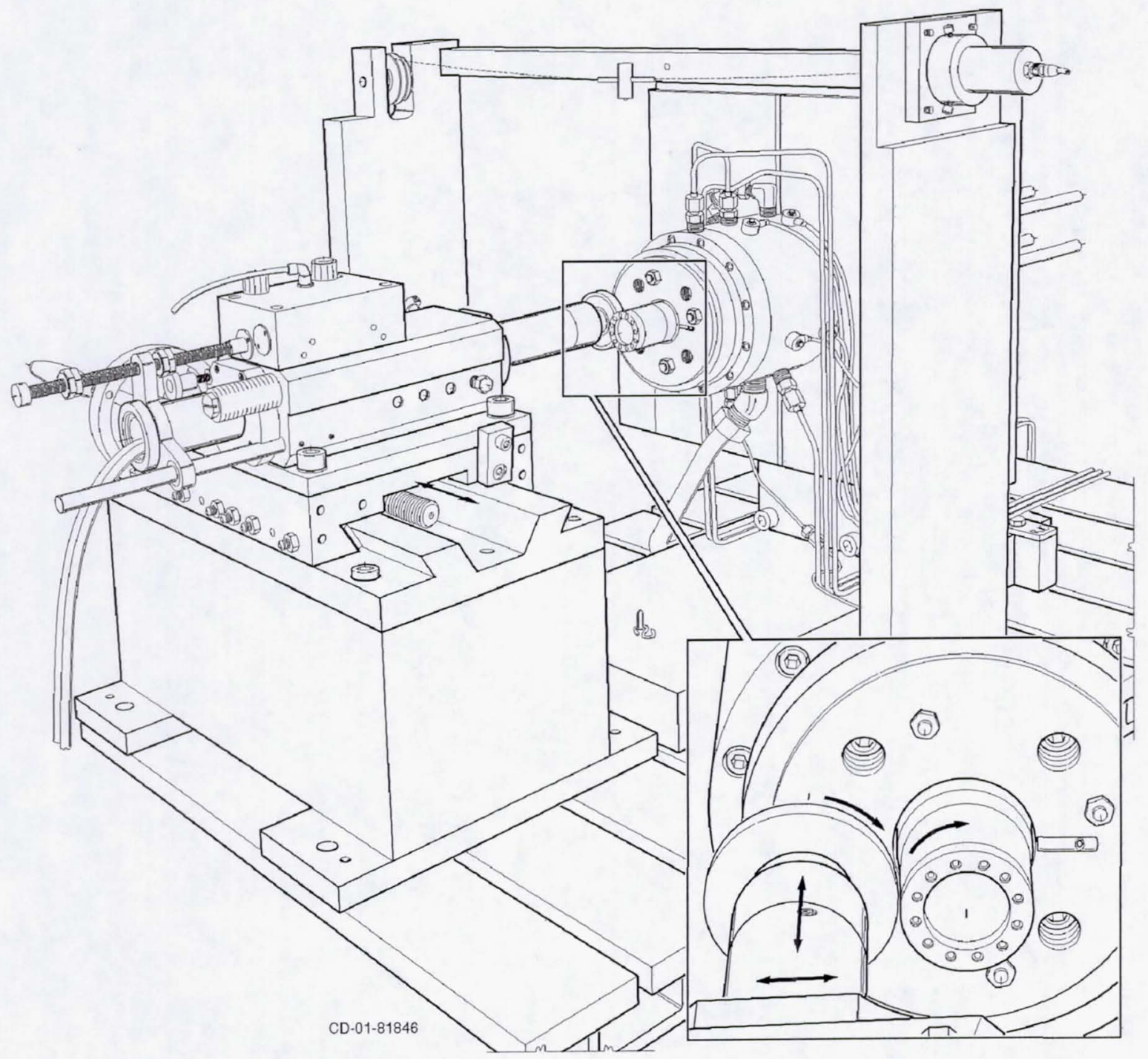

Figure 4.-Setup of the in-place grinding system. 


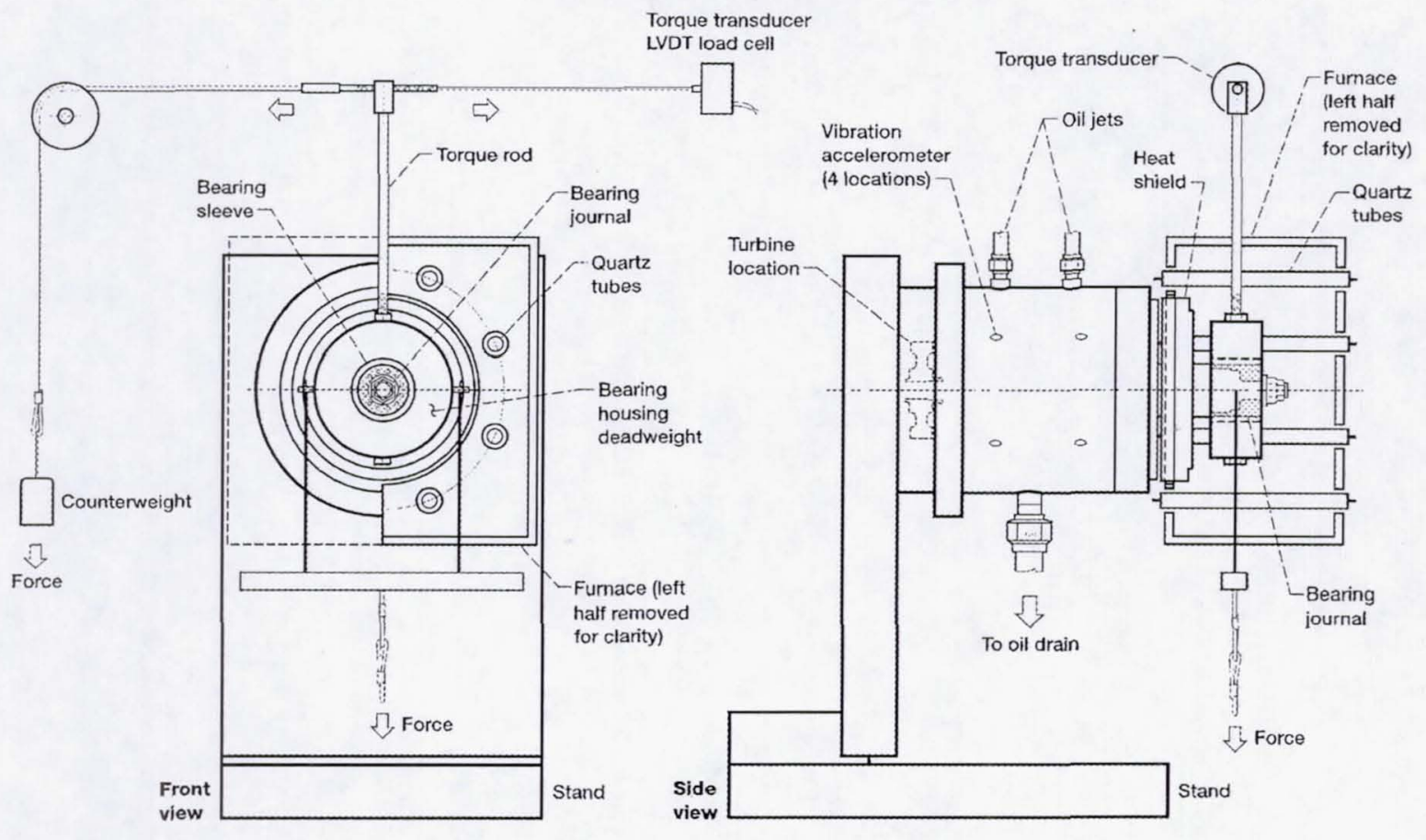

Figure 5.-Front and side views of the high-temperature, high-speed foil bearing test rig.

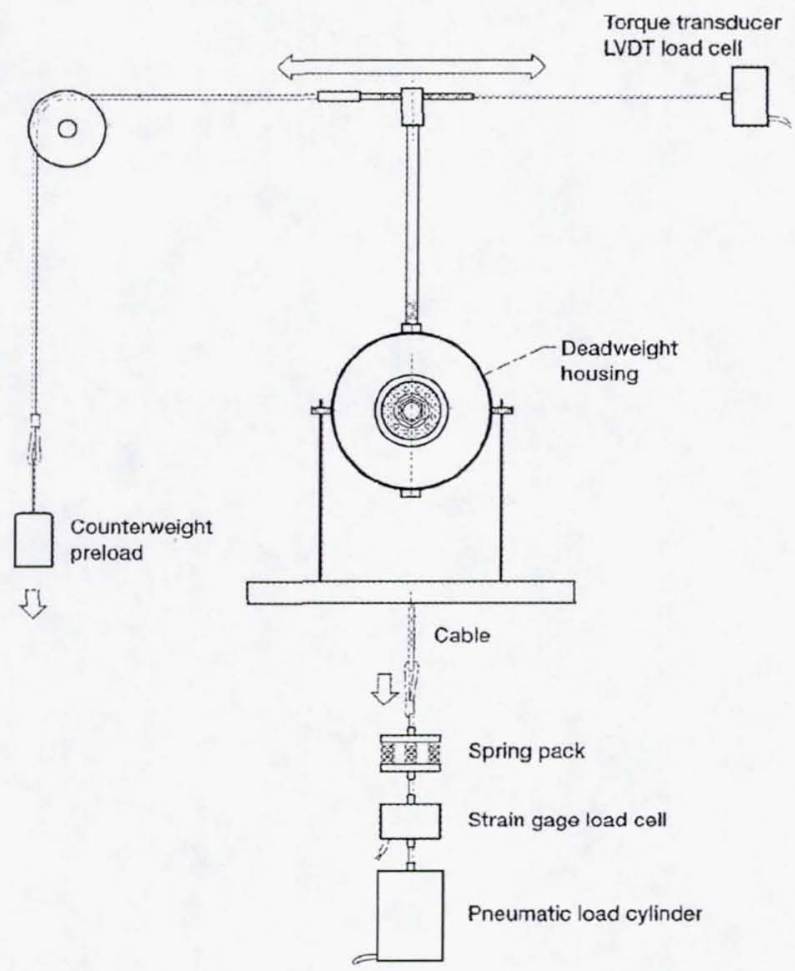

Figure 6.-Drawing of the pneumatic loading mechanism and the torque measurement system. 


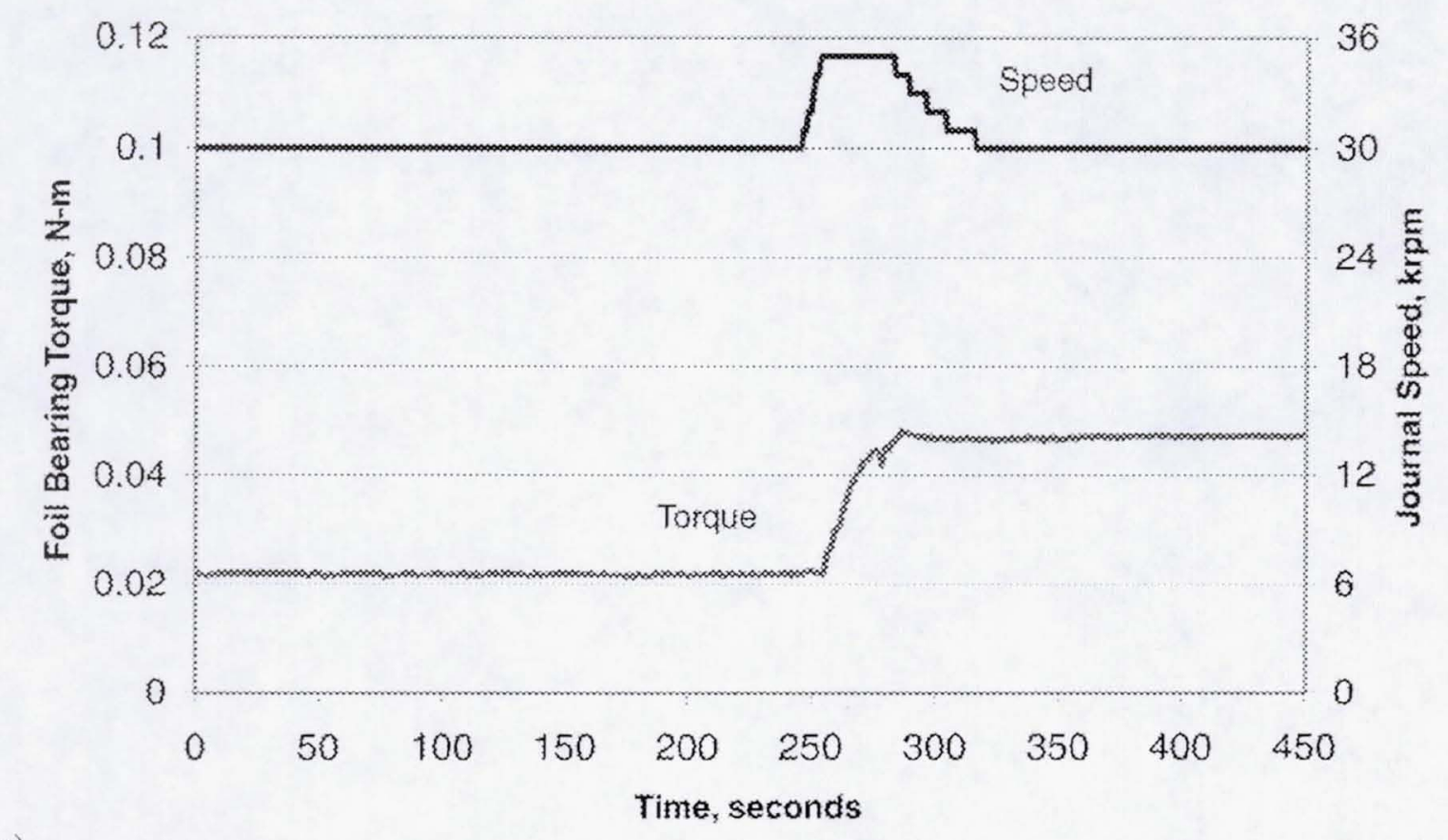

(a)

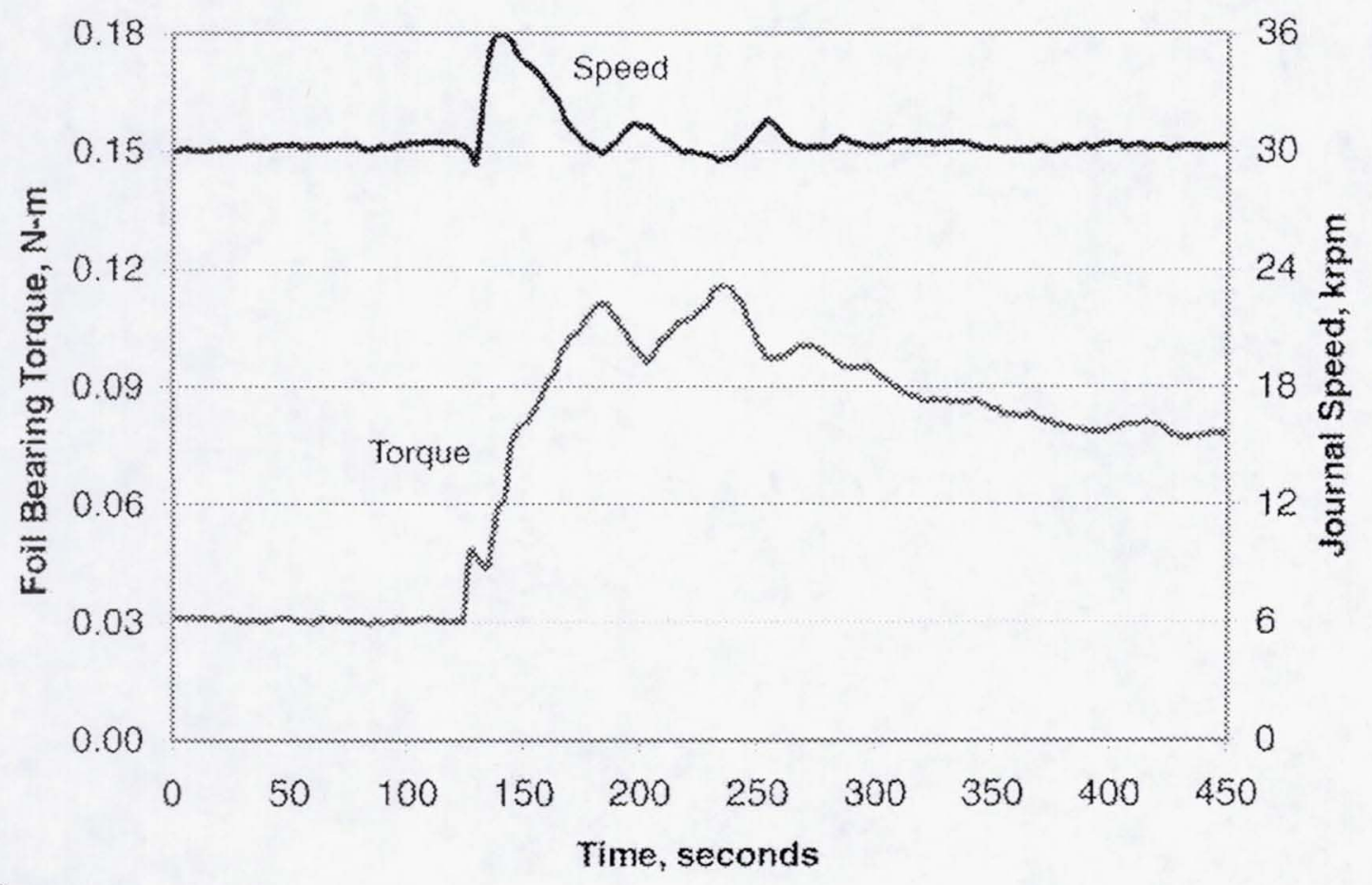

(b)

Figure 7.- Journal speed and bearing torque traces during an increase in applied load. (a) No indication of asperity contact. (b) High-speed polishing due to asperity contact between PS304 coating and bearing top foil. 


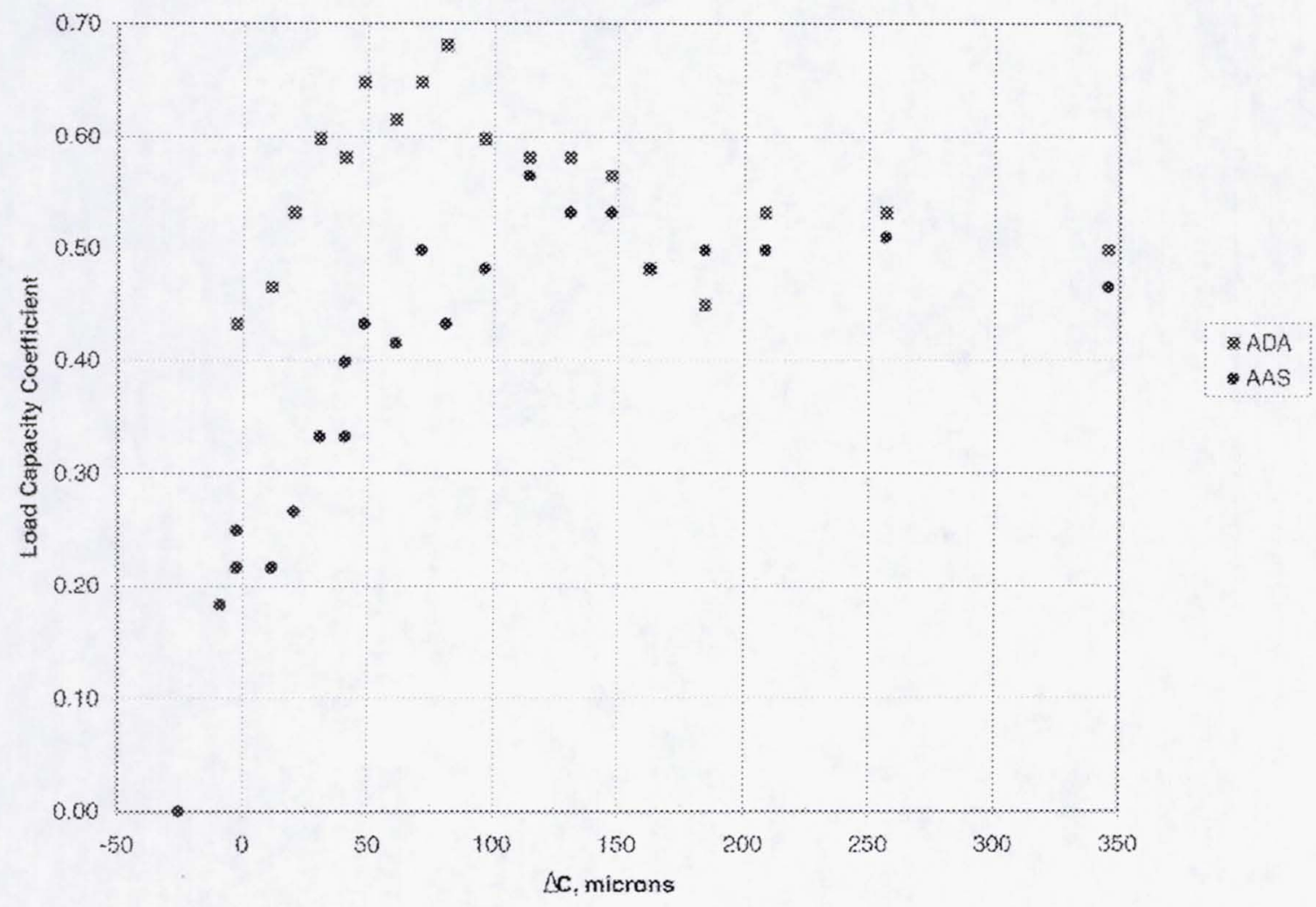

Figure 8.-Variation of the load capacity coefficient of the two test bearings plotted as a function of radial clearance. 


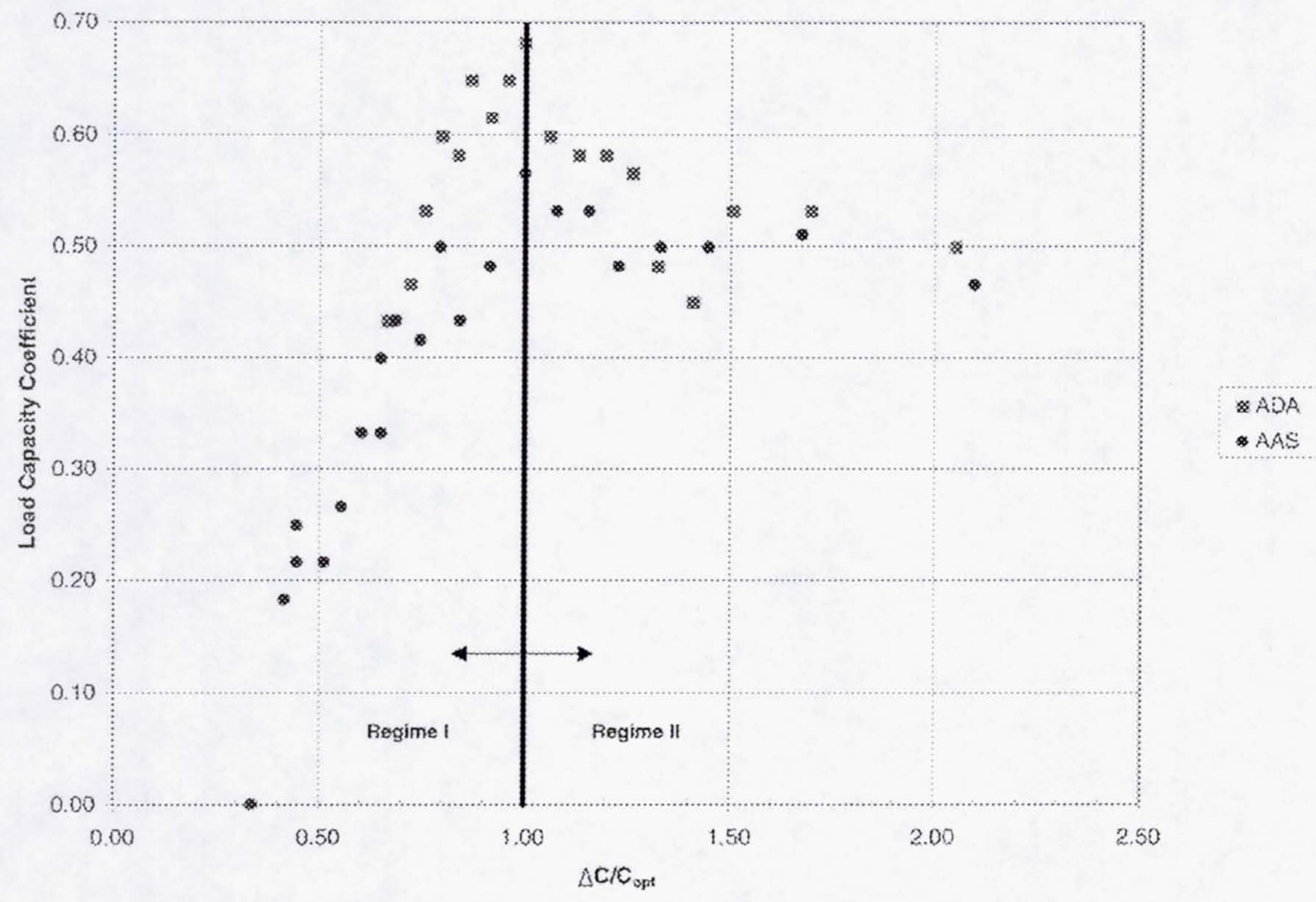

Figure 9.- Load capacity coefficients of the two test bearings versus radial clearance normalized with respect to the optimum. The two different failure regimes are shown. 
Public reporting burden for this collection of information is estimated to average 1 hour per response, including the time for reviewing instructions, searching existing data sources. gathering and maintaining the data needed, and completing and reviewing the collection of information. Send comments regarding this burden estimate or any other aspect of this
collection of information, including suggestions for reducing this burden, to Washington Headquarters Services, Directorate for Information Operations and Peports, 1215 Jefferson collection of information, including suggestions for reducing this burden, to Washington Headquarters Services, Directorate for Information Operations and Peports, 1215 Jefferson
Davis Highway, Suite 1204, Arlington, VA 22202-4302, and to the Office of Management and Budget, Paperwork Reduction Project (0704-0188), Washington, DC 20503.

\begin{tabular}{|l|l|l|}
\hline 1. AGENCY USE ONLY (Leave blank) & $\begin{array}{r}\text { 2. REPORT DATE } \\
\text { July } 2002\end{array}$ & $\begin{array}{r}\text { 3. REPORT TYPE AND DATES COVERED } \\
\text { Technical Memorandum }\end{array}$ \\
\hline
\end{tabular}

\section{TITLE AND SUBTITLE}

The Role of Radial Clearance on the Performance of Foil Air Bearings

6. $\operatorname{AUTHOR}(\mathrm{S})$

Kevin Radil, Samuel Howard, and Brian Dykas

7. PERFORMING ORGANIZATION NAME(S) AND ADDRESS(ES)

National Aeronautics and Space Administration

John H. Glenn Research Center at Lewis Field

Cleveland, Ohio 44135-3191

9. SPONSORING/MONITORING AGENCY NAME(S) AND ADDRESS(ES)

National Aeronautics and Space Administration

Washington, DC 20546-0001

and

U.S. Army Research Laboratory

Adelphi, Maryland 20783-1145

11. SUPPLEMENTARY NOTES

Prepared for the International Joint Tribology Conference cosponsored by the American Society of Mechanical Engineers and the Society of Tribologists and Lubrication Engineers, Cancun, Mexico, October 27-30, 2002. Kevin Radil, U.S. Army Research Laboratory, NASA Glenn Research Center; Samuel Howard, NASA Glenn Research Center; and Brian Dykas, Ohio Aerospace Institute, Brook Park, Ohio 44142. Responsible person, Kevin Radil, organization code 5960, 216-433-5047.

12a. DISTRIBUTION/AVAILABILITY STATEMENT

Unclassified - Unlimited

Subject Category: 07

Distribution: Nonstandard

Available electronically at http://gltrs.grc.nasa.gov/GLTRS

This publication is available from the NASA Center for AeroSpace Information, 301-621-0390.

13. ABSTRACT (Maximum 200 words)

Load capacity tests were conducted to determine how radial clearance variations affect the load capacity coefficient of foil air bearings. Two Generation III foil air bearings with the same design but possessing different initial radial clearances were tested at room temperature against an as-ground PS304 coated journal operating at $30000 \mathrm{rpm}$. Increases in radial clearance were accomplished by reducing the journal's outside diameter via an in-place grinding system. From each load capacity test the bearing load capacity coefficient was calculated from the rule-of-thumb (ROT) model developed for foil air bearings. The test results indicate that, in terms of the load capacity coefficient, radial clearance has a direct impact on the performance of the foil air bearing. Each test bearing exhibited an optimum radial clearance that resulted in a maximum load capacity coefficient. Relative to this optimum value are two separate operating regimes that are governed by different modes of failure. Bearings operating with radial clearances less than the optimum exhibit load capacity coefficients that are a strong function of radial clearance and are prone to a thermal runaway failure mechanism and bearing seizure. Conversely, a bearing operating with a radial clearance twice the optimum suffered only a 20 percent decline in its maximum load capacity coefficient and did not experience any thermal management problems. However, it is unknown to what degree these changes in radial clearance had on other performance parameters, such as the stiffness and damping properties of the bearings.

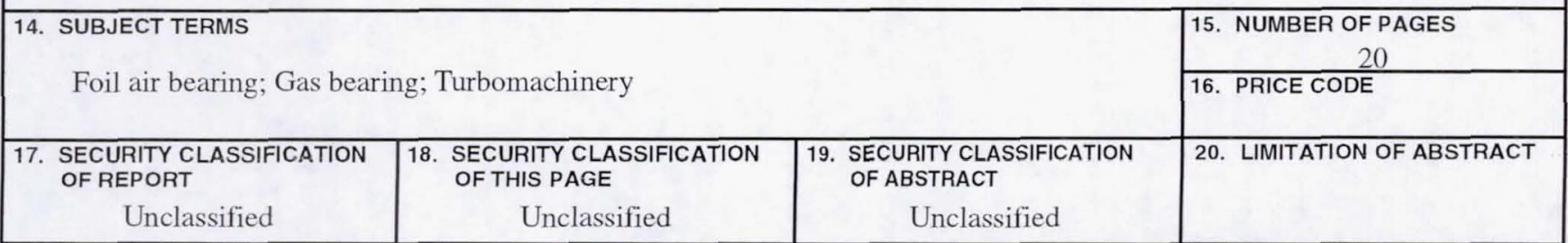

NSN 7540-01-280-5500

Standard Form 298 (Rev. 2-89)

Prescribed by ANSI Std. Z39-18 298-102 